\title{
Prawny status zawodu lekarza. Wybrane zagadnienia
}

\section{Wprowadzenie}

Zawód lekarza, jeden z najważniejszych zawodów medycznych, wymaga odrębnej analizy w aspekcie statusu prawnego. Istotna jest zwłaszcza odpowiedź na pytanie, czy lekarz wykonujący swój zawód podejmuje i prowadzi działalność gospodarcza, uzyskując status przedsiębiorcy, czy też jego status jest inny, szczególny.

W średniowiecznej Anglii rozwinęła się koncepcja tzw. zawodów powszechnych (ang. common callings czy public employments) ${ }^{1}$. Na przedstawicielach takich zawodów, jak kowale, kupcy, piwowarzy, kramarze, zdobnicy, oberżyści, drukarze, ale także cyrulicy (pełniący w tamtych czasach funkcje medyczne), ciążył szczególny (feudalny) obowiązek świadczenia usług (ang. duty to serve) na rzecz wszystkich, bez różnicy

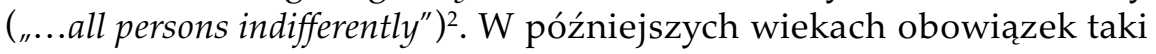

${ }^{1}$ Na temat tzw. zawodów powszechnych zob. szerzej w: J. Basedow, Common Carriers Continuity and Disintegration in U.S. Transportation Law, "Transportation Law Journal" 1984, no. 13, s. 4 i n. Por. nadto: S.R. Wild, A History of Railroad Abandonments, "Transportation Law Journal" 1996, vol. 23, no. 3, s. 2, oraz W.A. Mogel, J.P. Gregg, Appropriateness of Imposing Common Carrier Status on Interstate Natural Gas Pipelines, "Energy Law Journal” 2004, vol. 25, s. 30-34.

2 Tak w orzeczeniu Izby Lordów w sprawie Gisbourn v. Hurst z 1710 r. (91 Eng. Rep. 220). 
uzasadniano jako mający podstawę w „zwyczaju królestwa” (custom of the realm) ${ }^{3}$.

W XVII w. Sir Matthew Hale ${ }^{4}$ w swym traktacie pt. De Portibus Maris (1670) pisał, że te usługi i dobra, co do których w interesie publicznym jest zapewnienie ich dostępności, przestają pozostawać jedynie w domenie prywatnej (łac. iuris privati). Tym samym umiejscowione zostaja w domenie publicznej ${ }^{5}$. Co więcej, opłaty pobierane za dane dobra i usługi winny być rozsądne i umiarkowane (ang. reasonable and moderate).

\section{Pojęcia zawodu i wolnego zawodu}

W literaturze prawniczej najwięcej uwagi poświęcono ogólnie zawodom prawniczym, a w szczególności statusowi radcy prawnego. Analiza statusu prawnego zawodu lekarza bezsprzecznie wymaga wyjaśnienia licznych pojęć, jak pojęcie zawodu, wolnego zawodu, zawodu regulowanego czy zawodu zaufania publicznego.

K. Wojtczak w swej pracy pt. Zawód i jego prawna reglamentacja. Studium z zakresu materialnego prawa administracyjnego wskazuje, że niezwykle trudno jest zdefiniować pojęcie zawodu. Autorka podkreśla szeroki, interdyscyplinarny charakter tego pojęcia (socjologiczny, ekonomiczny, jurydyczny). Zdaniem autorki wyróżnić należy co najmniej cztery elementy składowe pojęcia: po pierwsze, określoną aktywność (zespół czynności, zakres czynności, szeroki rodzaj działalności; według J. Szczepańskiego "system czynności wewnętrznie spójny" $\left.{ }^{6}\right)$, po drugie, wymagane kwalifikacje (związek z pojęciami "zawód wyuczony" i „zawód wykonywany”), po trzecie, trwały (systematyczny) charakter, oraz po czwarte, cel zarobkowy (dostarczenie środków na utrzymanie, działalność mająca na celu zaspokojenie potrzeb życiowych $)^{7}$. Proponowana definicja zawodu według K. Wojtczak brzmi następująco:

${ }^{3}$ Tak w orzeczeniach Izby Lordów z 1684 r. w sprawie Jackson v. Rogers (89 Eng. Rep. 968) czy z 1838 r. w sprawie Gozzi v. Shipton (112 Eng. Rep. 1106).

${ }^{4}$ Ówczesny przewodniczący angielskiego Sądu Królewskiej Ławy (King's Bench obecnie odpowiednik Izby Karnej Sądu Najwyższego, czyli Izby Lordów).

5 "For now the wharf and crane and other conveniences are affected with a publick interest, and they cease to be juris privati only...", http://buckleysmix.com/wp-content/ uploads/2011/01/Hale-De-Portibus-Maris.docx (dostęp: 12 VI 2016).

${ }^{6}$ Zob. J. Szczepański, Czynniki kształtujace zawód i strukturę zawodowa, w: Socjologia zawodów, pod red. A. Sarapaty, Warszawa 1965, s. 12 i n.

${ }^{7}$ K. Wojtczak, Zawód i jego prawna reglamentacja. Studium z zakresu materialnego prawa administracyjnego, Poznań 1999, s. 32-35. 
„zawodem jest osobiste wykonywanie wewnętrznie spójnego zbioru czynności (zadań), wymagających określonych kwalifikacji (wiedzy lub umiejętności), systematycznie i odpłatnie, na podstawie i w granicach obowiązującego porządku prawnego" ${ }^{\prime \prime}$.

Bez wątpienia, pojęcie zawodu ma charakter interdyscyplinarny, m.in. socjologiczny, ekonomiczny, prawniczy. Należy zwrócić uwagę, że zawód stanowi element podziału pracy w społeczeństwie, element życia zbiorowego, uwarunkowany historycznie i zmieniający się na przestrzeni czasu w relacji do przemian społecznych, gospodarczych i naukowo-technicznych ${ }^{9}$.

Zawód w ujęciu jurydycznym stanowi bardziej pojęcie prawnicze aniżeli prawne. Stanowi wytwór nauki (doktryny) prawa, zaś w aktach prawnych prawie nie występuje. Jako pojęcie prawne na gruncie polskich przepisów definiowany jest jedynie w Rozporządzeniu Ministra Pracy i Polityki Społecznej z dnia 7 sierpnia 2014 r. w sprawie klasyfikacji zawodów i specjalności na potrzeby rynku pracy oraz zakresu jej stosowania ${ }^{10}$, wydanym na podstawie art. 36 ust. 8 Ustawy z dnia 20 kwietnia 2004 r. o promocji zatrudnienia i instytucjach rynku pracy ${ }^{11}, \mathrm{w}$ następujący sposób: „zawód stanowi źródło dochodów i oznacza zestaw zadań (czynności) wyodrębnionych w wyniku społecznego podziału pracy, wymagających kompetencji nabytych w toku uczenia się lub praktyki; specjalność obejmuje część zawodu, wymagającą dodatkowych kompetencji"12.

$\mathrm{Z}$ kolei pojęcie "wolnego zawodu" jest pojęciem występującym expressis verbis między innymi w art. 86-94 Kodeksu spółek handlowych $^{13}$ (regulacja prawna spółki partnerskiej). Zgodnie z art. 86 § 1 i 2,

\footnotetext{
${ }^{8}$ Ibidem, s. 50.

${ }^{9}$ Por. D. Karkowska, Zawody medyczne, Warszawa 2012, s. 39.

${ }^{10}$ Dz.U. poz. 1145.

${ }^{11}$ Tekst jedn. Dz.U. 2016, poz. 645 ze zm.
}

${ }^{12}$ Definicja zawarta jest w części rozporządzenia zatytułowanej „Objaśnienia do struktury klasyfikacji zawodów i specjalności na potrzeby rynku pracy". Wcześniej pojęcie zawodu definiowały: Rozporządzenie Ministra Pracy i Polityki Społecznej z dnia 27 IV 2010 r. w sprawie klasyfikacji zawodów i specjalności na potrzeby rynku pracy oraz zakresu jej stosowania (tekst jedn. Dz.U. 2014, poz. 760) i Rozporządzenie Ministra Pracy i Polityki Społecznej z dnia 8 XII 2010 r. w sprawie klasyfikacji zawodów i specjalności na potrzeby rynku pracy oraz zakresu jej stosowania (Dz.U. Nr 265, poz. 2644 ze zm.) - jako „zbiór zadań (zespół czynności) wyodrębnionych w wyniku społecznego podziału pracy, wykonywanych stale lub z niewielkimi zmianami przez poszczególne osoby i wymagających odpowiednich kwalifikacji (wiedzy i umiejętności), zdobytych w wyniku kształcenia lub praktyki. Wykonywanie zawodu stanowi źródło dochodów".

${ }^{13}$ Ustawa z dnia 15 IX 2000 r. Kodeks spółek handlowych (tekst jedn. Dz.U. 2013, poz. 1030 ze zm.), dalej "k.s.h.”. 
w części zatytułowanej „Objaśnienia do struktury klasyfikacji zawodów i specjalności na potrzeby rynku pracy”, "Spółką partnerską jest spółka osobowa, utworzona przez wspólników (partnerów) w celu wykonywania wolnego zawodu w spółce prowadzącej przedsiębiorstwo pod własną firmą. Spółka może być zawiązana w celu wykonywania więcej niż jednego wolnego zawodu, chyba że odrębna ustawa stanowi inaczej". Zgodnie z art. 87 \& 1 k.s.h. „Partnerami w spółce mogą być wyłącznie osoby fizyczne, uprawnione do wykonywania wolnych zawodów, określonych w art. 88 lub w odrębnej ustawie". Wreszcie art. 88 k.s.h. stanowi: "Partnerami w spółce mogą być osoby uprawnione do wykonywania następujących zawodów: adwokata, aptekarza, architekta, inżyniera budownictwa, biegłego rewidenta, brokera ubezpieczeniowego, doradcy podatkowego, maklera papierów wartościowych, doradcy inwestycyjnego, księgowego, lekarza, lekarza dentysty, lekarza weterynarii, notariusza, pielęgniarki, położnej, radcy prawnego, rzecznika patentowego, rzeczoznawcy majątkowego i tłumacza przysięgłego". Kodeks wymienia więc dwadzieścia zawodów określonych jako "wolne zawody”. Brak jednakże treści pojęcia „wolnego zawodu”. Przywołany przepis art. 88 k.s.h. wskazuje jedynie, jakie zawody zalicza się do „wolnych zawodów”. Stąd wydaje się, że trafnie A. Kidyba wskazuje - ze względu na brak wielu cech wspólnych łączących wymienione zawody - iż "określenie wolnych zawodów w Kodeksie spółek handlowych jest nadużyciem"14.

Co więcej, podkreślenia wymaga, że brak jest definicji wolnego zawodu w słowniczku ustawowym w art. 4 k.s.h.

W przeszłości podobnie do Kodeksu spółek handlowych definiowała wolny zawód Ustawa z dnia 26 lipca 1991 r. o podatku dochodowym od osób fizycznych ${ }^{15}$. Zgodnie z nieobowiązującym już przepisem art. 14a u.p.d.o.f. "[z]a przychody uzyskane $\mathrm{z}$ wykonywania wolnego zawodu, o których mowa w art. 13 pkt 8 i art. 14, uważa się przychody z osobiście wykonywanej działalności, w szczególności: lekarzy wszystkich specjalności, techników dentystycznych, felczerów, położnych, pielęgniarek, prawników, ekonomistów, inżynierów, architektów, techników budowlanych, geodetów, rzeczników patentowych, tłumaczy oraz księgowych"16.

${ }^{14}$ A. Kidyba, Radca prawny: zawód wolny, regulowany czy przedsiębiorca?, „Radca Prawny. Zeszyty Naukowe" 2014, nr 1, s. 14.

15 Tekst jedn. Dz.U. 2012, poz. 361 ze zm., dalej „u.p.d.o.f.”.

${ }^{16}$ Przepis dodany z dniem 1 I 1995 r. przez art. 1 pkt 7 Ustawy z dnia 2 XII 1994 r. o zmianie niektórych ustaw regulujących zasady opodatkowania oraz niektórych innych 
Na gruncie przywołanego art. 14a u.p.d.o.f. zapadł wyrok Naczelnego Sądu Administracyjnego - Ośrodek Zamiejscowy w Łodzi z dnia 19 stycznia 2001 r. (sygn. I SA/Łd 2578/98), w którym sąd wskazał: „Należy $\mathrm{w}$ tym miejscu zauważyć, że $\mathrm{w}$ stanie prawnym obowiązującym w datach wydania zaskarżonych decyzji nie istniała definicja tzw. wolnego zawodu. Jedynie art. 14a ustawy o podatku dochodowym od osób fizycznych zawierał przykładowe wyliczenie wolnych zawodów. Wśród nich znajdował się także zawód technika budowlanego, a więc zawód skarżącego. Wobec braku ustawowej definicji wolnego zawodu należy przedstawić najistotniejsze jego cechy. Do nich należy z pewnością osobiste świadczenie pracy lub usług przez osobę zwykle posiadająca specjalistyczną wiedzę fachową potwierdzoną stosownymi uprawnieniami. Jednocześnie zaś cechą najbardziej charakterystyczną dla wolnego zawodu jest brak podporządkowania i zależności służbowej osoby wykonującej pracę lub świadczącej usługi, a także wykonywanie jej na własny rachunek"17.

Pozostając w sferze przepisów podatkowych, aktualnie pojęcie wolnego zawodu występuje w Ustawie z dnia 29 sierpnia 1997 r. Ordynacja podatkowa ${ }^{18}$, której art. 3 pkt $9^{19}$ definiuje działalność gospodarczą jako "każdą działalność zarobkową w rozumieniu przepisów o swobodzie działalności gospodarczej, w tym wykonywanie wolnego zawodu, a także każdą inną działalność zarobkową wykonywaną we własnym imieniu i na własny lub cudzy rachunek, nawet gdy inne ustawy nie zaliczają tej działalności do działalności gospodarczej lub osoby wykonującej taką działalność - do przedsiębiorców". Jak widać, definicję tę cechują wszystkie niedoskonałości (wady) definicji wcześniej przytaczanych ${ }^{20}$.

Należy zauważyć, że na gruncie przepisów Unii Europejskiej (UE) w ust. 43 preambuły do Dyrektywy 2005/36/WE Parlamentu Europejskiego i Rady z dnia 7 września 2005 r. w sprawie uznawania kwalifikacji

ustaw (Dz.U. Nr 5, poz. 25). Następnie przepis skreślony z dniem 1 I 2001 r. na podstawie art. 1 pkt 11 Ustawy z dnia 9 XI 2000 r. o zmianie ustawy o podatku dochodowym od osób fizycznych oraz o zmianie niektórych innych ustaw (Dz.U. Nr 104, poz. 1104 ze zm.).

${ }^{17}$ M. Stolarek, Opodatkowanie wolnego zawodu, „Przegląd Podatkowy” 1998, nr 6, s. 5.

18 Tekst jedn. Dz.U. 2015, poz. 613 ze zm., dalej „o.p.”.

${ }^{19}$ Przepis dodany z dniem 1 I 2003 r. przez art. 1 pkt 2 lit. d Ustawy z dnia 12 IX 2002 r. o zmianie ustawy - ordynacja podatkowa oraz o zmianie niektórych innych ustaw (Dz.U. Nr 169, poz. 1387 ze zm.).

${ }^{20}$ Definicja krytykowana m.in. przez A. Kidybę. A. Kidyba, op. cit., s. 13. 
zawodowych ${ }^{21}$ wskazuje się sześć cech wolnych zawodów ${ }^{22}$. Są to następujące cechy: osobiste wykonywanie działalności, na podstawie odpowiednich kwalifikacji zawodowych, odpowiedzialne wykonywanie, zawodowe wykonywanie, niezależność wykonywania oraz przez osoby świadczące usługi intelektualne i koncepcyjne w interesie klienta i w interesie publicznym ${ }^{23}$.

W doktrynie definicję wolnego zawodu konstruuje K. Wojtczak ${ }^{24}$, wskazując następujące elementy pojęcia: po pierwsze, szczególny charakter aktywności (charakter intelektualny, umysłowy czy ewentualnie z przewagą tego elementu), po drugie, kwalifikacje zawodowe (wysokie kwalifikacje zawodowe), po trzecie, niezależność i wolność od jakiegokolwiek podporządkowania, po czwarte, samodzielność w wykonywaniu zawodu, po piąte, szczególny charakter relacji pomiędzy osobą wykonującą wolny zawód a odbiorcą usługi (opierający się zasadniczo na zaufaniu; jeden z najważniejszych i tradycyjnie najlepiej charakteryzujących istotę wolnego zawodu elementów; z drugiej strony zauważa się obecność takiego elementu także w relacjach np. $z$ bankami i zakładami ubezpieczeniowymi), po szóste, odpłatność świadczenia (honorarium swobodnie ustalane pomiędzy stronami, ale też możliwość występowania kryterium „bezinteresowności”), po siódme, element społecznej misji (funkcja służby publicznej; korelacja z tradycyjną nazwą stosowaną do dnia dzisiejszego: „służba zdrowia”), po ósme, odpowiedzialność (pełna osobista odpowiedzialność majątkowa za szkody wyrządzone na skutek popełnionego błędu, niezależna od odpowiedzialności zawodowej lub dyscyplinarnej), oraz, po dziewiąte, przynależność do korporacji zawodowej i akceptacja deontologii zawodowej ${ }^{25}$.

${ }^{21}$ Dz.Urz. UE L 255 z 30 IX 2005 r., s. 22.

${ }^{22}$ Ust. 43 preambuły: „W zakresie, w jakim są one regulowane, niniejsza dyrektywa dotyczy również wolnych zawodów, do których, zgodnie z niniejszą dyrektywą, należą zawody wykonywane osobiście na podstawie odpowiednich kwalifikacji zawodowych w sposób odpowiedzialny i zawodowo niezależny przez osoby świadczące usługi intelektualne i koncepcyjne $\mathrm{w}$ interesie klienta i w interesie publicznym. Wykonywanie zawodu może podlegać w Państwach Członkowskich, zgodnie z Traktatem, szczególnym ograniczeniom ustawowym zgodnie z prawem krajowym oraz uregulowaniom zawodowym przyjmowanym w tych ramach samodzielnie przez odpowiednie organizacje zawodowe, chroniącym i rozwijającym profesjonalizm oraz jakość usług, a także poufność w relacjach z klientem".

${ }^{23}$ Ostatnie kryterium zdaje się być niezwykle trafne i cenne przy definiowaniu wolnego zawodu. Por. A. Kidyba, op. cit., s. 15.

${ }^{24} \mathrm{~K}$. Wojtczak, op. cit.

${ }^{25}$ To kryterium nie jest powszechnie przyjęte w polskiej i obcej literaturze. Por. ibidem, s. 76 . 
Co do kryterium samodzielności w wykonywaniu wolnego zawodu należy zauważyć, że dla niektórych przedstawicieli doktryny występowanie podległości czy nadzoru nie wyklucza zakwalifikowania danego zawodu do wolnego zawodu (dotyczyć to może również lekarza zatrudnionego $\mathrm{w}$ podmiocie leczniczym). Istotne $\mathrm{w}$ tym przypadku jest ponoszenie "pełnej odpowiedzialności osobistej, moralnej i zawodowej za wolne i całkowite wykonywanie swej dyscypliny"26. Rozróżnić należy w tym miejscu samodzielność intelektualną i ekonomiczno-finansowa, zwracając uwagę na problematykę prawnej formy prowadzenia działalności oraz wykonywania działalności na własny rachunek ${ }^{27}$. Przedstawioną argumentację wspiera orzecznictwo Sądu Najwyższego $(\mathrm{SN})^{28}$. W wyroku z 7 września $1999 \mathrm{r} .{ }^{29}$ Sąd Najwyższy tworzy pojęcie "podporządkowania autonomicznego": „W miejsce dawnego systemu ścisłego hierarchicznego podporządkowania pracownika i obowiązku stosowania się do dyspozycji pracodawcy nawet w technicznym zakresie działania pojawia się nowe podporządkowanie autonomiczne polegające na wyznaczaniu pracownikowi przez pracodawcę zadań bez ingerowania w sposób wykonania tych zadań. W nowym systemie podporządkowania pracodawca określa godziny czasu pracy i wyznacza zadania, natomiast sposób realizacji tych zadań pozostawiony jest pracownikowi. Ten nowy system podporządkowania autonomicznego jest szczególnie widoczny w przypadku pracowników wykonujących zawody twórcze, gdyż szczególnie im pracodawca pozostawia istotny margines swobody co do sposobu realizacji powierzonego im $\mathrm{w}$ ramach stosunku pracy zadania".

Z kolei przy kryterium odpłatności świadczenia podkreśla się w literaturze, że osoby wykonujące wolne zawody nie powinny przedkładać swego interesu nad interesy im powierzone. Zauważa się też realistycznie, że bezinteresowność osób wykonujących wolne zawody jest współcześnie fikcją ${ }^{30}$. Jednocześnie podkreśla się, że cechą zawodu lekarza, „bardziej niż np. adwokata”, jest ratowanie życia i zdrowia bez względu na kondycję materialno-finansową pacjenta ${ }^{31}$.

${ }^{26}$ Ibidem, s. 71.

${ }^{27}$ Zob. M. Święcki, Pojęcie wolnego zawodu lekarza, "Gazeta Lekarska” 2001, nr 9, s. 1.

${ }^{28}$ Por. K. Stoga, D. Szubielska, Dwugłos radców prawnych dotyczacy statusu radcy prawnego, "Radca Prawny. Zeszyty Naukowe” 2015, nr 3(4), s. 21.

${ }^{29}$ Wyrok SN z 7 IX 1999 r., sygn. I PKN 277/99, Orzecznictwo Sądu Najwyższego. Izba Administracyjna, Pracy i Ubezpieczeń Społecznych 2001, nr 1, poz. 18.

${ }^{30}$ K. Wojtczak, op. cit., s. 74.

${ }^{31}$ M. Święcki, op. cit. 
W literaturze prawniczej J. Jacyszyn wskazuje następujące cechy wolnego zawodu: po pierwsze, kwalifikowane, szczególne wykształcenie, po drugie, specyficzne zasady wykonywania zawodu, po trzecie, niezależność zawodowa, po czwarte, etos i misja wykonywania zawodu, po piąte, sposób i stan zorganizowania, po szóste, etyka zawodowa, po siódme, odmienny od typowej zapłaty charakter wynagrodzenia, po ósme, tajemnica zawodowa, oraz po dziewiąte, szczególna odpowiedzialność karna i cywilna, porządkowa i korporacyjna ${ }^{32}$.

Z kolei U. Promińska wskazuje na: po pierwsze, specjalne przygotowanie zawodowe, po drugie, osobiste i samodzielne świadczenie usług, po trzecie, działanie na własną odpowiedzialność, oraz po czwarte, wysokie ryzyko wykonywania zawodu (charakter zagrożonych dóbr; konieczność dołożenia najwyższej staranności w świadczeniu usług) ${ }^{33}$.

A. Kidyba trafnie zauważa, że niektóre wolne zawody (księgowy, broker ubezpieczeniowy) nie wymagają szczególnego (specjalnego) wykształcenia ${ }^{34}$.

Definicję wolnego zawodu formułuje K. Wojtczak w następujący sposób: „wolnym zawodem jest osobiste i samodzielne wykonywanie wewnętrznie spójnego zespołu czynności o charakterze intelektualnym, wymagających wysokich kwalifikacji (wiedzy i praktyki), systematycznie, w zamian za honorarium bezinteresownie ustalone, służące zapewnianiu świadczeń lub usług klientom oraz ochronie istotnych wartości interesu ogólnego, zgodnie z obowiązującymi normami prawnymi, zasadami etycznymi i deontologicznymi" ${ }^{\prime \prime}$.

W orzecznictwie na szczególną uwagę zasługuje wyrok Trybunału Konstytucyjnego (TK) z 19 października 1999 r. ${ }^{36}$ W Części III.3 uzasadnienia do tego wyroku znajduje się stwierdzenie: „W odniesieniu zaś do tzw. wolnych zawodów treścią wolności wykonywania zawodu jest stworzenie sytuacji prawnej, w której: po pierwsze, każdy mieć będzie swobodny dostęp do wykonywania zawodu, warunkowany tylko talentami i kwalifikacjami; po drugie, mieć będzie następnie rzeczywistą

32 J. Jacyszyn, Spółka partnerska według przepisów ustawy Kodeks spółek handlowych. Komentarz, Bielsko-Biała 2000, s. 77 i n.

${ }^{33}$ U. Promińska, Zdolność do osiagnięcia statusu partnera, § 2 „Wykonywanie wolnego zawodu", w: Spótka partnerska, pod red. A. Kidyby, Warszawa 2013, s. 99.

${ }^{34}$ A. Kidyba, op. cit., s. 14.

${ }^{35}$ K. Wojtczak, op. cit., s. 112.

${ }^{36}$ Wyrok TK z 19 X 1999 r., sygn. SK 4/99, Orzecznictwo Trybunału Konstytucyjnego. Zbiór Urzędowy (OTK ZU) 1999, nr 6, poz. 119. 
możliwość wykonywania swojego zawodu oraz - po trzecie, nie będzie przy wykonywaniu zawodu poddany rygorom podporządkowania, które charakteryzują świadczenie pracy".

\section{Pojęcia zawodu medycznego, zawodu lekarza i wolnego zawodu lekarza}

Pojęcie zawodu medycznego występuje w art. 2 ust. 1 pkt 2 Ustawy z dnia 15 kwietnia 2011 r. o działalności leczniczej ${ }^{37}$. Zgodnie z przywołanym przepisem osoba wykonująca zawód medyczny to osoba uprawniona "na podstawie odrębnych przepisów do udzielania świadczeń zdrowotnych oraz osoba legitymująca się nabyciem fachowych kwalifikacji do udzielania świadczeń zdrowotnych w określonym zakresie lub w określonej dziedzinie medycyny" ${ }^{\prime \prime 8}$. Jak widać, zakres przedmiotowy zawodu medycznego oddany zostaje pojęciem „świadczenia zdrowotnego" ${ }^{\prime \prime}$, do którego szeroko odwoływała się Ustawa z dnia 30 sierpnia 1991 r. o zakładach opieki zdrowotnej ${ }^{40}$, a obecnie ustawa o działalności leczniczej z 2011 r. $^{41}$

Z kolei ustawa z grudnia 1996 r. o zawodach lekarza i lekarza dentysty $^{42}$ definiuje pojęcie "wykonywania zawodu lekarza”. Zgodnie $\mathrm{z}$ art. 2 ust. 1 przywołanej ustawy "[w]ykonywanie zawodu lekarza polega na udzielaniu przez osobę posiadającą wymagane kwalifikacje, potwierdzone odpowiednimi dokumentami, świadczeń zdrowotnych, w szczególności: badaniu stanu zdrowia, rozpoznawaniu chorób i zapobieganiu im, leczeniu i rehabilitacji chorych, udzielaniu porad lekarskich, a także wydawaniu opinii i orzeczeń lekarskich". Zgodnie z art. 2 ust. 3 tejże ustawy "[z]a wykonywanie zawodu lekarza uważa się także prowadzenie przez lekarza prac badawczych w dziedzinie nauk medycznych lub promocji zdrowia, nauczanie zawodu lekarza, kierowanie podmiotem

37 Tekst jedn. Dz.U. 2015, poz. 618 ze zm.

${ }^{38}$ Wcześniej pojęcie zawodu medycznego występowało w art. $18 \mathrm{~d}$ ust. 1 pkt 1 Ustawy z dnia 30 VIII 1991 r. o zakładach opieki zdrowotnej (tekst jedn. Dz.U. 2007 Nr 14, poz. 89 ze zm.).

${ }^{39}$ D. Karkowska, op. cit., s. 74 i n.

${ }^{40}$ Tekst jedn. Dz.U. 2007 Nr 14, poz. 89 ze zm.

${ }^{41}$ Zob. art. 2 ust. 1 pkt 10 (definicja ustawowa świadczenia zdrowotnego), art. 3 ust. 1 , art. 8 , art. 9 ust. $1-2$ i n.

${ }^{42}$ Ustawa z dnia 5 XII 1996 r. o zawodach lekarza i lekarza dentysty (tekst jedn. Dz.U. 2015, poz. 464 ze zm.). 
leczniczym, o którym mowa w art. 4 ustawy z dnia 15 kwietnia 2011 r. o działalności leczniczej (Dz.U. z 2013 r. poz. 217, z późn. zm.) lub zatrudnienie $w$ podmiotach zobowiązanych do finansowania świadczeń opieki zdrowotnej ze środków publicznych w rozumieniu przepisów ustawy z dnia 27 sierpnia 2004 r. o świadczeniach opieki zdrowotnej finansowanych ze środków publicznych (Dz.U. z 2008 r. Nr 164, poz. 1027, z późn. zm.) lub urzędach te podmioty obsługujących, w ramach którego wykonuje się czynności związane z przygotowywaniem, organizowaniem lub nadzorem nad udzielaniem świadczeń opieki zdrowotnej". Co więcej, "[1]ekarz, lekarz dentysta może wykonywać czynności, o których mowa w ust. 1 i 2, także za pośrednictwem systemów teleinformatycznych lub systemów łączności" (art. 2 ust. 4 ustawy).

Kluczowy jest nadto przepis art. 4 ustawy o zawodach lekarza i lekarza dentysty, zgodnie z którym: „[1]ekarz ma obowiązek wykonywać zawód, zgodnie ze wskazaniami aktualnej wiedzy medycznej, dostępnymi mu metodami i środkami zapobiegania, rozpoznawania i leczenia chorób, zgodnie z zasadami etyki zawodowej oraz z należytą starannością".

Definicja "wolnego zawodu lekarza" występuje wyłącznie w literaturze. Według M. Święckiego "zawód lekarza to wolny zawód (zaufania publicznego), który polega na osobistym wykonywaniu z należytą starannością i w sposób niezależny czynności służących ochronie zdrowia i życia ludzi, zgodnie ze wskazaniami aktualnej wiedzy medycznej, dostępnymi metodami i środkami oraz przepisami prawa i zasadami etyki zawodowej przez osobę posiadającą wymagane kwalifikacje potwierdzone uzyskaną licencją oraz innymi dokumentami uprawniającymi do zarobkowego udzielania świadczeń zdrowotnych określonego rodzaju ( $w$ formie indywidualnej lub grupowej praktyki lekarskiej albo na podstawie umowy o pracę bądź umowy cywilno-prawnej"43.

\section{Lekarz jako zawód zaufania publicznego}

Pojęcie "zawodu zaufania publicznego" stanowi pojęcie właściwe wyłącznie dla polskiego prawodawstwa i polskiej doktryny prawa. Nie występuje ono $\mathrm{w}$ żadnym innym państwie ${ }^{44}$. Zgodnie $\mathrm{z}$ art. 17 ust. 1

${ }^{43}$ M. Święcki, op. cit., s. 2.

${ }^{44}$ Por. P. Antkowiak, Polskie i europejskie standardy wykonywania wolnych zawodów, „Przegląd Politologiczny” 2013, nr 1, s. 135; A. Krasnopolski, Zawody zaufania publicznego, zawody regulowane oraz wolne zawody. Geneza, funkcjonowanie oraz aktualne problemy, Biuro 
Konstytucji Rzeczypospolitej Polskiej ${ }^{45}$ "[w] drodze ustawy można tworzyć samorządy zawodowe, reprezentujące osoby wykonujące zawody zaufania publicznego i sprawujące pieczę nad należytym wykonywaniem tych zawodów w granicach interesu publicznego i dla jego ochrony".

Należy zauważyć, że są zawody zaufania publicznego stanowiące jednocześnie wolne zawody i zawody zaufania publicznego. Istnieją jednakże wolne zawody niezaliczające się do zawodów zaufania publicznego. Za nieprawidłowy należy uznać pogląd, wedle którego zawody zaufania publicznego z zasady oznaczają zawody zrzeszone w samorządach zawodowych (korporacjach) ${ }^{46}$. Trybunał Konstytucyjny w pkt 4.4 uzasadnienia wyroku z 24 marca 2015 r. ${ }^{47}$ wyraźnie stwierdza: „Utworzenie samorządów, o których mowa w art. 17 Konstytucji, jest pozostawione ocenie ustawodawcy".

Kluczowy przy rozróżnieniu wolnego zawodu i zawodu zaufania publicznego jest element szczególnego interesu publicznego realizowanego przez przedstawicieli danego zawodu.

Również w przywołanym wyroku z 24 marca 2015 r., w pkt 3.4 uzasadnienia, Trybunał Konstytucyjny formułuje trafną definicję pojęcia "zawodu zaufania publicznego": "Trybunał aprobuje w niniejszej sprawie dotychczasowe orzecznictwo co do rozumienia pojęcia zawodu zaufania publicznego i na tej podstawie, jak również z uwzględnieniem poglądów wyrażonych w doktrynie prawniczej, przyjął, że do cech takiego zawodu należą:

a) konieczność zapewnienia prawidłowego i zgodnego z interesem publicznym wykonywania zawodu, ze względu na znaczenie, jakie dana dziedzina aktywności zawodowej ma w społeczeństwie,

b) udzielanie świadczeń i wchodzenie przez przedstawicieli omawianych zawodów w kontakty z osobami fizycznymi w razie wystąpienia potencjalnego lub realnego zagrożenia dóbr o szczególnym charakterze (np. życia, zdrowia, wolności, godności, dobrego imienia),

Analiz i Dokumentacji, Zespół Analiz i Opracowań Tematycznych, Kancelaria Senatu, listopad 2013, s. 3, 11-12.

${ }^{45}$ Konstytucja Rzeczypospolitej Polskiej z dnia 2 IV 1997 r. (Dz.U. Nr 78, poz. 483 ze zm. ), dalej „Konstytucja RP”.

${ }^{46}$ Tak A. Krasnopolski, op. cit., s. 3. Podobnie zdaje się myśleć P. Antkowiak (op. cit., s. 131-134), aczkolwiek expressis verbis takiej tezy nie formułuje.

${ }^{47}$ Wyrok TK z 24 III 2015 r., sygn. K 19/14, TK-A 2015/3/32. Zob. glosa aprobująca: M. Jackowski, Glosa do wyroku TK z dnia 24 marca 2015 r., K 19/14, „Palestra” 2015, z. 9-10, s. 179 i n. 
c) staranność i dbałość przedstawicieli omawianych zawodów o interesy osób korzystających z ich usług, troska o ich osobiste potrzeby, a także zapewnienie ochrony gwarantowanych przez Konstytucję praw podmiotowych jednostek,

d) wymaganie szczególnych kwalifikacji do wykonywania omawianych zawodów, obejmujących nie tylko odpowiednie, formalne wykształcenie, ale także nabyte doświadczenie oraz dawanie rękojmi należytego i zgodnego z interesem publicznym wykonywania zawodu, z uwzględnieniem szczególnych norm deontologii zawodowej,

e) pozyskiwanie informacji osobistych i dotyczących życia prywatnego osób korzystających z usług przedstawicieli zawodu zaufania publicznego; informacje te stanowią tajemnicę zawodową, a zwolnienie z niej może nastąpić na zasadach określonych w przepisach ustawy z dnia 6 czerwca 1997 r. - Kodeks postępowania karnego (Dz.U. Nr 89, poz. 555 , ze zm.),

f) względna samodzielność wykonywania zawodu"48.

\section{Lekarz jako zawód regulowany}

Pojęcie "zawodu regulowanego" stanowi pojęcie unijne. Definicja zawodu regulowanego (ang. regulated profession, fr. profession réglementée, niem. reglementierter Beruf) znajduje się w art. 3 ust. 1 pkt a Dyrektywy 2005/36/WE Parlamentu Europejskiego i Rady z dnia 7 września 2005 r. w sprawie uznawania kwalifikacji zawodowych ${ }^{49}$ i zgodnie $z$ nią zawód regulowany to "działalność zawodowa lub zespół działalności zawodowych, których podjęcie, wykonywanie lub jeden ze sposobów wykonywania wymaga, bezpośrednio bądź pośrednio, na mocy przepisów ustawowych, wykonawczych lub administracyjnych, posiadania specjalnych kwalifikacji zawodowych; w szczególności używanie tytułu zawodowego zastrzeżonego na mocy przepisów ustawowych, wykonawczych i administracyjnych dla osób posiadających odpowiednie kwalifikacje zawodowe stanowi sposób wykonywania działalności

${ }^{48}$ Podobnie w poprzednich wyrokach TK (przywołanych w pkt 3.3 uzasadnienia wyroku w sprawie K 19/14): z 7 III 2012 r., sygn. K 3/10 (OTK ZU 2012, nr 3/A, poz. 25); z 26 III 2008 r., sygn. K 4/07 (OTK ZU 2008, nr 2/A, poz. 28); z 2 VII 2007 r., sygn. K 41/05 (OTK ZU 2007, nr 7/A, poz. 72); z 8 XI 2006 r., sygn. K 30/06 (OTK ZU 2006, nr 10/A, poz. 149); z 22 V 2001 r., sygn. K 37/00 (OTK ZU 2001, nr 4, poz. 86).

${ }^{49}$ Dz.Urz. UE L 255 z 30 IX 2005 r., s. 22. 
zawodowej. W przypadkach, w których nie stosuje się pierwszego zdania niniejszej definicji, działalność zawodowa, o której mowa w ust. 2, traktowana jest jako zawód regulowany".

Zawód lekarza uregulowany jest w dyrektywie 2005/36/WE w art. 22-30 (lekarze specjaliści, lekarze ogólni), pielęgniarek - art.31-33, lekarzy dentystów - art. 34-37, lekarzy weterynarii - art. 38-39, położnych - art. 40-43(b).

Definicja zawodu regulowanego zawarta jest także w polskiej Ustawie z dnia 22 grudnia 2015 r. o zasadach uznawania kwalifikacji zawodowych nabytych w państwach członkowskich Unii Europejskiej ${ }^{50}$, $\mathrm{w}$ art. 5 pkt 4 . Zgodnie z tym przepisem zawód regulowany „oznacza [...] zespół czynności zawodowych, których wykonywanie jest uzależnione od posiadania określonych $\mathrm{w}$ przepisach regulacyjnych formalnych kwalifikacji niezbędnych do wykonywania tych czynności zawodowych oraz, o ile jest to wymagane, od spełnienia innych warunków określonych w tych przepisach" ${ }^{\prime 51}$. Wymieniona ustawa definiuje nadto pojęcia „działalności regulowanej” oraz „wykonywania zawodu” ${ }^{2}$.

${ }^{50}$ Dz.U. 2016, poz. 65. Data wejścia w życie 18 I 2016 r. Wcześniejsza ustawa z dnia 18 III 2008 r. o zasadach uznawania kwalifikacji zawodowych nabytych w państwach członkowskich Unii Europejskiej (Dz.U. Nr 63, poz. 394 ze zm.) definiowała zawód regulowany $\mathrm{w}$ art. 2 ust. 1 pkt 1 .

${ }^{51}$ Wcześniejsza ustawa z dnia 18 III 2008 r. o zasadach uznawania kwalifikacji zawodowych nabytych w państwach członkowskich Unii Europejskiej, uchylona z dniem 18 I 2016 r. przez art. 88 Ustawy z dnia 22 XII 2015 r. o zasadach uznawania kwalifikacji zawodowych nabytych w państwach członkowskich Unii Europejskiej, definiowała zawód regulowany w art. 2 ust. 1 pkt 1 jako „zespół czynności zawodowych, których wykonywanie jest uzależnione od spełnienia wymagań kwalifikacyjnych i warunków okreśślonych w odrębnych polskich przepisach, zwanych dalej "przepisami regulacyjnymi»".

${ }^{52}$ Działalność regulowana "oznacza [...] działalność wymienioną w załączniku IV (różne działalności, jak działalność wykonywana bez stałej lokalizacji = domokrążcy, handel obwoźny; wynajem samochodów, powozów i koni, maszyn, usługi pralnicze, fotograficzne, rybołówstwo śródlądowe, budowa i naprawa statków, taboru kolejowego, produkcja sprzętu latającego, w tym międzyplanetarnego itd.; lekarze - załącznik V) do dyrektywy 2005/36/WE Parlamentu Europejskiego i Rady z dnia 7 IX 2005 r. w sprawie uznawania kwalifikacji zawodowych (Dz.Urz. UE L 255 z 30.09.2005, str. 22, z późn. zm.), zwanej dalej «dyrektywą», jeżeli jej podejmowanie lub wykonywanie w Rzeczypospolitej Polskiej jest uzależnione od spełnienia wymagań kwalifikacyjnych oraz, o ile jest to wymagane, warunków określonych w przepisach regulacyjnych". Wykonywanie zawodu "oznacza [...] wykonywanie zawodu na własny rachunek, na podstawie umowy o pracę albo w innej formie dozwolonej przez przepisy obowiązujące w państwie członkowskim, w którym zawód był, jest lub ma być wykonywany". Na rozróżnienie pojęć zawodu regulowanego i działalności regulowanej uwagę zwracają m.in. K. Stoga i D. Szubielska (op. cit., s. 15-16). 


\section{Wolny zawód lekarza a działalność gospodarcza i przedsiębiorca}

Przedwojenne Rozporządzenie Prezydenta Rzeczypospolitej z dnia 7 czerwca 1927 r. o prawie przemysłowem ${ }^{53}$ stanowiło w art. 2 pkt 13, że „[n] $\left[\right.$ ie są przemysłem ${ }^{54} \mathrm{~W}$ rozumieniu niniejszego rozporządzenia i przepisom jego nie podlegają: praca zawodowa lekarzy, lekarzy weterynaryjnych, farmaceutów, felczerów, dentystów, techników dentystycznych, położnych, pielęgniarzy, sanitarjuszów, masażystów, kosmetyków" ${ }^{\prime 55}$.

Z kolei art. 3 Rozporządzenia Prezydenta Rzeczypospolitej z dnia 27 czerwca 1934 r. Kodeks handlowy ${ }^{56}$ stanowił: „Wykonywanie wolnego zawodu samo przez się nie jest przedsiębiorstwem zarobkowym" ${ }^{\prime 57}$. Kodeks handlowy uchylony został z dniem 1 stycznia 1965 r. przez Ustawę z dnia 23 kwietnia 1964 r. Przepisy wprowadzające kodeks cywilny ${ }^{58}$.

Pierwsze przyjęte po 1945 r. przepisy regulujące podejmowanie i wykonywanie działalności gospodarczej, tj. Ustawa z dnia 23 grudnia 1988 r. o działalności gospodarczej ${ }^{59}$, w art. 24 ust. 1 objęła zakresem przedmiotowym pojęcia działalności gospodarczej świadczenie pomocy prawnej (obsługi prawnej) podmiotom gospodarczym w zakresie

${ }^{53}$ Dz.U. Nr 53, poz. 458 ze zm. Rozporządzenie uchylone z dniem 1 I 1973 r. przez art. 45 ust. 1 Ustawy z dnia 8 VI 1972 r. o wykonywaniu i organizacji rzemiosła (tekst jedn. Dz.U. 1983 Nr 7, poz. 40 ze zm.).

${ }^{54}$ Zgodnie z art. 1 Rozporządzenia Prezydenta Rzeczypospolitej z dnia 7 VI 1927 r. o prawie przemysłowem "przemysł to wszelkie zatrudnienie zarobkowe lub przedsiębiorstwo, wykonywane samoistnie i zawodowo, bez względu na to, czy jest ono wytwarzające, przetwarzające, handlowe lub usługowe".

${ }^{55}$ Podobnie art. 2 Rozporządzenia Prezydenta Rzeczypospolitej z dnia 7 VI 1927 r. o prawie przemysłowem wyłączał: zakłady lecznicze, zdrojowiska i uzdrowiska, ambulatorja, lecznice zwierzęce (art. 2 pkt 9), pracę zawodową adwokatów, obrońców sądowych, notarjuszów, inżynierów, architektów, budowniczych (techników budowlanych), geometrów, mierniczych, rzeczników patentowych (art. 2 pkt 11), apteki, laboratorja bakterjologiczne i do celów djagnostyki lekarskiej, wyrób i sprzedaż surowic, szczepionek, preparatów organo-terapeutycznych oraz produktów bakteryjnych leczniczych i zapobiegających chorobom, wyrób i sprzedaż substancyj i przetworów odurzających, detaliczną sprzedaż trucizn i środków leczniczych (art. 2 pkt 14) oraz wiele innych rodzajów działalności gospodarczej. Należy zauważyć, że zakres wyłączeń był bardzo szeroki i różnorodny (art. 2 miał 23 punkty).

${ }^{56}$ Dz.U. Nr 57, poz. 502 ze zm. Kodeks handlowy został uchylony z dniem 1 I 1965 r. przez art. VI $\S 1$ Ustawy z dnia 23 IV 1964 r. Przepisy wprowadzające kodeks cywilny (Dz.U. Nr 16, poz. 94 ze zm.).

${ }^{57}$ Por. A. Kidyba, op. cit., s. 20-21.

${ }^{58}$ Dz.U. Nr 16, poz. 94 ze zm. (art. VI $\S 1$ ustawy).

${ }^{59}$ Dz.U. Nr 41, poz. 324. 
ich działalności gospodarczej przez spółki i spółdzielnie, w których uczestniczą adwokaci lub radcowie prawni. Brak było bezpośredniego podmiotowego (czy przedmiotowego) wyłączenia spod obowiązywania ustawy względem jakiegokolwiek wolnego zawodu.

Z kolei Ustawa z dnia 19 listopada 1999 r. Prawo działalności gospodarczej ${ }^{60}$ (w wersji pierwotnej) w art. 87 wyraźnie wyłączyła świadczących pomoc prawną spod zakresu pojęcia przedsiębiorcy, stanowiąc, że podmioty wykonujące działalność polegającą na świadczeniu pomocy prawnej, określoną przepisami Ustawy z dnia 26 maja 1982 r. - Prawo o adwokaturze ${ }^{61}$ oraz Ustawy z dnia 6 lipca 1982 r. o radcach prawnych $^{62}$ nie są przedsiębiorcami. Przepis ten został zmieniony z dniem 22 sierpnia 2001 r. Ustawą z dnia 11 kwietnia 2001 r. o rzecznikach patentowych ${ }^{63}$ poprzez dodanie do art. 87 ust. 2, zgodnie z którym "[ś]wiadczący pomoc w zakresie własności przemysłowej nie jest przedsiębiorcą w rozumieniu przepisów niniejszej ustawy. Działalność polegającą na świadczeniu pomocy w zakresie własności przemysłowej określają przepisy ustawy z dnia 11 kwietnia 2001 r. o rzecznikach patentowych"64.

Zgodnie z aktualną regulacją prawną art. 4 ust. 1 Ustawy z dnia 2 lipca 2004 r. o swobodzie działalności gospodarczej ${ }^{65}$ "przedsiębiorca w rozumieniu ustawy jest osoba fizyczna, osoba prawna i jednostka organizacyjna niebędąca osobą prawną, której odrębna ustawa przyznaje zdolność prawną - wykonująca we własnym imieniu działalność gospodarczą". Podobnie, acz nie identycznie, stanowi art. $43^{1}$ Kodeksu cywilnego ${ }^{66}$.

Działalnością gospodarczą z kolei (art. 2 u.s.d.g.) jest zarobkowa działalność wytwórcza, budowlana, handlowa, usługowa oraz poszukiwanie, rozpoznawanie i wydobywanie kopalin ze złóż, a także działalność zawodowa, wykonywana w sposób zorganizowany i ciągły.

${ }^{60}$ Dz.U. Nr 101, poz. 1178.

${ }^{61}$ Tekst jedn. Dz.U. 2015, poz. 615 ze zm.

${ }^{62}$ Tekst jedn. Dz.U. 2016, poz. 233 ze zm.

${ }^{63}$ Dz.U. Nr 49, poz. 509 ze zm.

${ }^{64}$ Tekst jedn. Dz.U. 2016, poz. 221 ze zm.

${ }^{65}$ Tekst jedn. Dz.U. 2015, poz. 584 ze zm., dalej „u.s.d.g.”.

${ }^{66}$ Ustawa z dnia 23 IV 1964 r. Kodeks cywilny (tekst jedn. Dz.U. 2014, poz. 121 ze zm.), dalej „k.c.”. Art. $43^{1}$ k.c. dodany z dniem 25 IX 2003 r. przez Ustawę z dnia 14 II 2003 r. o zmianie ustawy - Kodeks cywilny oraz niektórych innych ustaw (Dz.U. Nr 49, poz. 408). Zob. na temat różnic pomiędzy art. 4 u.s.d.g. a art. $43^{1}$ k.c. w: J. Jacyszyn, Wokót statusu prawnego radcy prawnego, „Radca Prawny. Zeszyty Naukowe” 2015, nr 1(2), s. 18-20. 
Ustawa z dnia 15 kwietnia 2011 r. o działalności leczniczej67 w art. 2 definiuje m.in. następujące pojęcia: osoby wykonującej zawód medycz$n y^{68}$, podmiotu leczniczego niebędącego przedsiębiorcą (samodzielne publiczne zakłady opieki zdrowotnej, jednostki budżetowe, jednostki wojskowe) oraz podmiotu wykonującego działalność leczniczą ${ }^{69}$.

Zgodnie $z$ art. 3 u.dz.l. działalność lecznicza polega na udzielaniu świadczeń zdrowotnych (art. 3 ust. 1) oraz polegać może również na promocji zdrowia lub realizacji zadań dydaktycznych i badawczych w powiązaniu z udzielaniem świadczeń zdrowotnych i promocją zdrowia, w tym wdrażaniem nowych technologii medycznych oraz metod leczenia (art. 3 ust. 2).

Ustawa o działalności leczniczej wyróżnia osiem kategorii podmiotów leczniczych: przedsiębiorcy w rozumieniu przepisów Ustawy z dnia 2 lipca 2004 r. o swobodzie działalności gospodarczej, samodzielne publiczne zakłady opieki zdrowotnej, jednostki budżetowe (w tym państwowe jednostki budżetowe tworzone i nadzorowane przez ministra obrony narodowej, ministra właściwego do spraw wewnętrznych, ministra sprawiedliwości lub szefa Agencji Bezpieczeństwa Wewnętrznego), instytuty badawcze, fundacje i stowarzyszenia, jednostki organizacyjne stowarzyszeń posiadające osobowość prawna, osoby prawne i jednostki organizacyjne działające na podstawie przepisów o stosunku państwa do Kościoła katolickiego w Rzeczypospolitej Polskiej, o stosunku państwa do innych Kościołów i związków wyznaniowych oraz o gwarancjach wolności sumienia i wyznania, a także jednostki wojskowe - w zakresie, w jakim wykonują działalność leczniczą (art. 4 u.dz.l.).

Działalność lecznicza samych lekarzy zgodnie z ustawą o działalności leczniczej może być wykonywana albo w formie jednoosobowej działalności gospodarczej jako indywidualna praktyka lekarska, indywidualna praktyka lekarska wyłącznie w miejscu wezwania, indywidualna specjalistyczna praktyka lekarska, indywidualna specjalistyczna praktyka lekarska wyłącznie w miejscu wezwania, indywidualna praktyka lekarska wyłącznie w przedsiębiorstwie podmiotu leczniczego na

${ }^{67}$ Tekst jedn. Dz.U. 2015, poz. 618 ze zm., dalej „u.dz.l.”.

${ }^{68}$ Osoba uprawniona na podstawie odrębnych przepisów do udzielania świadczeń zdrowotnych oraz osoba legitymująca się nabyciem fachowych kwalifikacji do udzielania świadczeń zdrowotnych w określonym zakresie lub w określonej dziedzinie medycyny (art. 2 pkt 2 u.dz.l.).

${ }^{69}$ Podmiot leczniczy, o którym mowa w art. 4 u.dz.l., oraz lekarz lub pielęgniarka wykonujący zawód w ramach działalności leczniczej jako praktykę zawodową, o której mowa w art. 5 u.dz.l. 
podstawie umowy z tym podmiotem lub indywidualna specjalistyczna praktyka lekarska wyłącznie w przedsiębiorstwie podmiotu leczniczego na podstawie umowy z tym podmiotem (art. 5 ust. 2 pkt 1 lit. a u.dz.l.) albo w formie spółki cywilnej, spółki jawnej lub spółki partnerskiej jako grupowa praktyka lekarska (art. 5 ust. 2 pkt 1 lit. b u.dz.l.).

Podjęcie i wykonywanie działalności leczniczej przez lekarzy uzależnione jest od wpisu do rejestru podmiotów wykonujących działalność leczniczą ${ }^{70}$ (art. 5 ust. 1 u.dz.l. $)^{71}$. Niemniej zgodnie z art. 5 ust. 3 u.dz.l. wykonywanie zawodu $\mathrm{w}$ ramach praktyki zawodowej nie jest prowadzeniem podmiotu leczniczego. W uzasadnieniu projektu ustawy o działalności leczniczej projektodawca podkreślił, że "wykonywanie zawodu medycznego w ramach praktyki zawodowej nie stanowi prowadzenia podmiotu leczniczego, co pozwoli na uniknięcie praktyki podwójnego wpisywania praktyki lekarskiej: do rejestru praktyk lekarskich (prowadzonego obecnie przez okręgowe izby lekarskie) i do rejestru zakładów opieki zdrowotnej - jako niepublicznego zakładu opieki zdrowotnej"72.

W konsekwencji, biorąc pod uwagę posiadanie statusu przedsiębiorcy, można wyróżnić dwie sytuacje prawne lekarzy:

- lekarze zatrudnieni w podmiotach leczniczych na podstawie umowy o pracę, niebędący przedsiębiorcami;

- lekarze przedsiębiorcy wykonujący praktykę zawodową jako jednoosobową działalność gospodarczą bądź w ramach grupowej praktyki lekarskiej (spółka cywilna, spółka jawna, spółka partnerska).

Tym samym działalność lecznicza (zawodowa) lekarzy będących przedsiębiorcami w oczywisty sposób będzie stanowić działalność gospodarczą. Z kolei działalność lekarzy niebędących przedsiębiorcami nie stanowi działalności gospodarczej, ale jedynie wykonywanie pracy.

Odnosząc się do szczegółowych aspektów przedstawionego wyżej rozróżnienia, należy podkreślić, że bezsprzecznie przedsiębiorcami są lekarze wykonujący działalność w ramach spółki cywilnej (art. 860-875 k.c.). Wynika to bezpośrednio z art. 4 ust. 2 u.s.d.g. („Za przedsiębiorców

${ }^{70}$ Rejestry prowadzą właściwi miejscowo (ze względu na siedzibę albo miejsce zamieszkania podmiotu leczniczego) wojewodowie bądź okręgowe rady lekarskie właściwe dla miejsca wykonywania praktyki zawodowej lekarzy, a dla członków wojskowej izby lekarskiej - Wojskowa Rada Lekarska (art. 106 ust. 1 pkt 1-2 u.dz.l.).

${ }^{71}$ Treść wniosku o wpis do rejestru podmiotów wykonujących działalność leczniczą reguluje art. 100 u.dz.l.

${ }^{72}$ Uzasadnienie projektu ustawy o działalności leczniczej, http://orka.sejm.gov.pl/ Druki6ka.nsf/0/430F945C6F0937D1C12577C200267BC8/\$file/3489-uzasadnienie.doc (dostęp: 12 VI 2016). 
uznaje się także wspólników spółki cywilnej w zakresie wykonywanej przez nich działalności gospodarczej") oraz z regulacji prawnej spółki partnerskiej (istota spółki partnerskiej, art. 86 § 1 k.s.h. i n.).

Co więcej, wydaje się że przedsiębiorcami są także lekarze wykonujący działalność w ramach spółki jawnej (niezależnie od tego, że przedsiębiorcami są dane spółki) ${ }^{73}$. Przedmiotowa teza znajduje uzasadnienie w regulacji art. 4 ust. 1 oraz art. 2 u.s.d.g., a także w art. $43^{1}$ k.c. Ponadto wspierają ją odwołania do subsydiarnej odpowiedzialności wspólników spółki jawnej za działalność spółki, szczególnej specyfiki zawodu lekarza polegającej na osobistym świadczeniu, szczególnej odpowiedzialności lekarza czy regulacji prawnej ubezpieczenia od odpowiedzialności cywilnej (OC) lekarzy, zawarte w ustawie o działalności leczniczej lekarzy ${ }^{74}$.

\section{Podsumowanie}

Zawód lekarza bezsprzecznie stanowi wolny zawód oraz zawód zaufania publicznego. Niezależnie od niniejszych rozważań można podać w wątpliwość celowość rozróżniania wolnego zwodu i zawodu zaufania publicznego jako odrębnych kategorii.

Wydaje się, że status zawodu wolnego oraz zawodu zaufania publicznego można przyznać także lekarzowi świadczącemu pracę na rzecz podmiotu leczniczego na podstawie umowy o pracę (występowanie tzw. „podporządkowania autonomicznego" - wyrok SN z 7 września 1999 r., sygn. I PKN 277/99).

${ }^{73}$ Por. odmienne stanowisko co do radców prawnych w: A. Kidyba, op. cit., s. 20. Por. rozważania dotyczące statusu radców prawnych nadto w: K. Stoga, D. Szubielska, op. cit., s. 30-31.

${ }^{74}$ Ustawa o działalności leczniczej nakłada na podmiot leczniczy obowiązek zawarcia umowy ubezpieczenia odpowiedzialności cywilnej oraz na rzecz pacjentów z tytułu zdarzeń medycznych (art. 17 ust. 1 pkt 4, art. 25 ust. 1 u.dz.l.). Kierownik jednostki zobowiązany jest przekazać stosowne dokumenty potwierdzające zawarcie umowy ubezpieczenia organowi prowadzącemu rejestr działalności regulowanej (art. 25 ust. 1 u.dz.l.). Jednakże wykonywanie zawodu $w$ ramach praktyki zawodowej nie jest prowadzeniem podmiotu leczniczego (art. 5 ust. 3 u.dz.l.). Co więcej, art. 18 ust. 7 u.dz.l. wyraźnie wskazuje, że lekarze wykonujący praktykę zawodową w ramach grupowej praktyki lekarskiej (wspólnicy albo partnerzy właściwych spółek) mają obowiązek zawarcia umowy ubezpieczenia OC (oraz spełniać te same warunki, co lekarze wykonujący indywidualną praktykę lekarską, przepisane w art. 18 ust. 1 bądź art. 18 ust. 2 u.dz.l.). 
Jednocześnie zawód lekarza to zawód regulowany w rozumieniu Dyrektywy 2005/36/WE Parlamentu Europejskiego i Rady z dnia 7 września 2005 r. w sprawie uznawania kwalifikacji zawodowych oraz Ustawy z dnia 22 grudnia 2015 r. o zasadach uznawania kwalifikacji zawodowych nabytych w państwach członkowskich Unii Europejskiej.

Lekarska praktyka zawodowa wykonywana jako indywidualna lub grupowa praktyka stanowi także działalność regulowaną w rozumieniu przepisów Ustawy z dnia 2 lipca 2004 r. o swobodzie działalności gospodarczej (wymagany właściwy wpis do rejestru działalności regulowanej - art. 101 ustawy o działalności leczniczej).

$Z$ punktu widzenia relacji zawodu lekarza i statusu przedsiębiorcy należy rozróżnić lekarzy zatrudnionych w podmiotach leczniczych na podstawie umowy o pracę (nieprzedsiębiorcy) oraz lekarzy wykonujących praktykę zawodową jako jednoosobową działalność gospodarczą bądź w ramach grupowej praktyki lekarskiej (spółka cywilna, spółka jawna, spółka partnerska; przedsiębiorcy).

W konsekwencji wydaje się, że zawód lekarza można określić jako swoisty „zawód hybrydalny", podobnie jak inne wolne zawody (w tym zawody zaufania publicznego) w Polsce ${ }^{75}$.

W literaturze zwraca się uwagę na trudność w pogodzeniu statusu zawodu zaufania publicznego oraz przedsiębiorcy (ma to się wzajemnie wykluczać $)^{76}$. Trudno się zgodzić z tak postawioną tezą. Nie znajduje ona poparcia w rzeczywistości. Poza tym słuszne wydaje się poddanie wolnych zawodów nie tylko prawnych regulacjom dotyczącym działalności gospodarczej (rejestry, obowiązki, uprawnienia przysługujące przedsiębiorcom) czy regulacjom w zakresie bilansowym i podatkowym, ale też poddanie tych działalności ekonomicznym prawom rynku, w tym wolnej konkurencji. Szczególna rola i funkcje lekarza oddane są przez jego status jako szczególnego zawodu wolnego oraz zawodu zaufania publicznego. $Z$ kolei odpowiednie obowiązki ciążące na lekarzach wynikają z przepisów prawa powszechnie obowiązującego oraz z deontologii zawodowej (np. obowiązek udzielania pomocy lekarskiej wynika z art. 30 ustawy o zawodach lekarza i lekarza dentysty oraz z Kodeksu etyki lekarskiej) $)^{77}$.

${ }^{75}$ Tak o zawodzie radcy prawnego J. Jacyszyn w pracy Wokół statusu prawnego..., s. 22.

${ }^{76}$ Zob. ibidem, s. 21.

77 Zob. L. Kubicki, Obowiazek udzielania pomocy lekarskiej, „Prawo i Medycyna” 2016, nr 13, http://www.prawoimedycyna.pl/sklep/709/obowiązek-udzielania-pomocy-lekarskiej/pismo-nr-13 (dostęp: 16 VI 2016). 


\section{THE LEGAL STATUS OF A PHYSICIAN IN POLAND. SOME SELECTED ISSUES}

\section{S u m m a ry}

The article deals with a very crucial question of the legal status of physicians in Poland. The question asked is whether a physician who works as a sole practitioner may be recognized as a person performing a liberal profession, a public trust profession (a category specific only as far as Polish domestic law concerned), or a regulated profession (according to Directive 2005/36/EC of the European Parliament and of the Council of 7 September 2005 on the recognition of professional qualifications). Consequently, first the concepts of a liberal, regulated and public trust professions are analysed.

Another important question to be answered is if physicians practicing as sole traders are undertakings in the meaning of the EU law and if they are what their status is.

The vastest exclusion in terms of the subject and object of the legislation was provided by the Regulation on Industrial Law issued by Poland's President on 7 June 1927 which excluded the activity conducted by physicians. Under Article 3 of the President's Regulation the Commercial Code 27 June 1934, all liberal professions were also excluded from activities considered to be a form of entrepreneurship. This attitude changed in postwar Poland and the Act of 23 December 1988 on Economic Activity provided for no exclusion for any liberal profession from being regarded as economic activity. The Act of 19 November 1999 on Economic Activity excluded from its scope only entities that provided legal services (barristers and solicitors) and those rendering services in the area of industrial property.

Today, under Polish law physicians are considered to be an undertaking in two situations: when they conduct their activities in the form of so-called 'private practice' (one-person undertaking), or when they conduct their practice within so-called 'collective practice' (partnership). They are not regarded as undertakings when they are employed by a medical institution or another medical entity on the basis of an employment contract. In such a case they fall under the provisions of the Act of 15 April 2011 on Medical Activities, but still keep the status of liberal profession.

Keywords: physicians - liberal profession - public trust profession - regulated profession - undertaking 